\section{Forest Products Research in the United States}

The valuable research work which has been carried out at the Forest Products Laboratory of the United States Forest Service, which is situated at Madison, Wis., is well known. According to Science Service, Washington, D.C., many difficulties are encountered in seasoning wood, and a treatment is being sought which will prevent, or greatly reduce, shrinking and swelling, thus removing one of wood's principal disadvantages. Fireretardant treatment is under investigation and several combinations of chemicals are said to give promise of practical results. Great improvements in the manufacture, preparation and use of glues have been made in the last decade. Experiments which are being undertaken appear to show that plastic compounds from chipped wood or pulp fibres have possibilities of competing with other products for panels, tiles, mouldings and other articles, a development which the lover of the genuine article will not regard with great pleasure. Some other problems awaiting solution are forecast by Mr. Arthur Koehler, the officer in charge of sylvicultural relations at the Forest Products Laboratory. For example, joints and joint fastenings, now the weakest part of wooden structures, require improvement. It is held that wood could be made more attractive by colouring with transparent dyes or treatment with gases, such as ammonia, increasing lustre by transparent coatings, or treatment of wood itself. On the subject of wood working machinery scientific study is required as, for example, the development of a planer which would leave no marks, thus eliminating sanding and raised grain troubles.

\section{Meteorological Records of Southport}

FEw towns possess such accurate and long meteorological records as Southport. This is largely due to the late Mr. Joseph Baxendell, whose work has been carried on and extended by his son, for many years meteorologist to the Southport Corporation. Each year's records are summarised and dis. cussed in an annual report; the report for the year 1931 has recently been published. There is a number of tables in these reports which differ in form from any of those appearing in the annual summaries of the Meteorological Office, and these add greatly to the value of the series. Among them may be mentioned those showing rainfall with different wind directions, diurnal variation of the duration of sunshine (totals for each hour of the day for each month) and mean level of subsoil water. This last table is a particularly interesting one. It has been maintained for forty-nine years, first of all by the late Mr. J. Baxendell at a private house in Liverpool Road, Birkdale, and later at 34 Kent Road, Birkdale, by Mr. James France and his wife. The record unfortunately ends at the close of the year under review, but alongside the last set of monthly figures appears similar information for the recently established meteorological station at Bedford Road Park, which is in the same part of Southport. To those not very familiar with this subject these single year's observations are not without interest, as they show differences of response to the meteorological conditions in spite of the proximity of the two wells used for making the measurements. June 1931 was very wet at Southport-5.99 inches of rain fell at Bedford Road Park-and the mean level of water in the shallower well at the older site rose in June almost to its February value, which was by no means the case at the other deeper well. The last six months of 1931 yielded altogether substantially more than the normal rainfall, but the average level of the shallower well almost returned to its normal value.

\section{Electrification of the Swedish State Railways}

THe primary object of electrifying the State railways in Sweden was to make them independent of foreign fuel. In 1920, when the project was first considered, the probable future price of locomotive coal was considered to be about $£ 8$ per ton. To make a more accurate estimate, local and English experts were consulted and they considered that the price would not fall below $£ 215 s$. per ton. In spite of these estimates, the price of coal has continued to fall. In 1923 it was less than $£ 2$ per ton, it then fluctuated for several years about $£ 1$ per ton and it was only 16s. a ton in 1931. These fluctuations in the price of coal make it difficult to estimate the economy effected by electrification. At present, two sections of the Swedish State Railways are in electrical operation; the Ore railway in the north (280 route miles) and the Stockholm-Göteborg line (285 route miles). The electrification has increased the carrying capacity of the Ore railway by about fifty per cent and the average speed of the trains has been doubled. In a paper on the Swedish railways read to the Institution of Electrical Engineers on January 5 , Mr. Öfverholm pointed out that the results on the Ore railway would have been more satisfactory if the existing station arrangements had been altered so as to allow longer trains to be employed. Considerable extensions of the system are being undertaken. By the end of the present year, 1,680 route miles of the State railways will be electrified. This corresponds to about forty per cent of the complete railway system. Several difficulties were experienced when electrification was first adopted. The disturbance on the telephone lines was obviated by suitably arranging the suspending wires of the power lines. By taking the power for the railway operation from the national distribution system, considerable economies were effected. The project of connecting the Swedish and Norwegian railways by a new bridge at Svinesund is being considered.

\section{Andaman and Nicobar Islands}

THE publication of the census report on the Andaman and Nicobar Islands (Census of India, 1931 : vol. 2. Calcutta: Central Publication Branch; $7 s .6 d$.) has given an opportunity for the production of a valuable monograph on the aborigines of these islands, the cultural anthropology of the Nicobar natives and various reports on the forests, 
agriculture and trade. Most of these reports are by Mr. C. J. Jonington, but several other writers have collaborated in the work. The Andaman population of 19,000 shows an increase, but this increase is solely in the convict and other immigrant population. The aborigines have fallen in number to $460 \mathrm{com}$ pared with 786 ten years ago, 1,317 in 1911, and nearly 5,000 when contact with an introduced population began in 1858 . There seems to be little hope of these races surviving. On the other hand, in the Nicobars, where there has been little disturbance with the natives or their tribal systems, the aboriginal population shows a steady increase during the last thirty years and is now nearly 10,000 . The figures in several of the islands are based on estimates but there is no reason to doubt their accuracy.

\section{Sterility in Domesticated Animals}

A USEFuL bulletin has been issued from the Imperial Bureau of Animal Genetics, Edinburgh, $(2 s .6 d$.$) , on the physiological and genetical aspects$ of sterility in domesticated animals. It is written by Dr. William Orr and Dr. F. Fraser Darling, and a full bibliography, prepared by Miss M. V. Cytovich, is appended. Succossive sections deal with physiological aberrations in the reproductive system, the nutritional aspects of sterility, and types of sterility referable to genetical causes. This will be of service not only to all those engaged in practical animal breeding kut also to those engaged in research on the physiological or genetical aspects of animal sterility.

\section{Centenary of Sir John Kirk}

IN connexion with the centenary on December 19 of Sir John Kirk (see Nature, 130, 920, Dec. 17, 1932), a portrait of Kirk was unveiled at the Zanzibar Museum, Zanzibar, by Sir Richard Rankine, British Resident for the Protectorate, in the presence of His Highness the Sultan. A number of exhibits associated with Sir John Kirk were displayed at the ceremony.

\section{Effect of the Preying of Birds on Butterflies}

Mr. C. L. Collenette writes from the Entomological Department, British Museum (Natural History), South Kensington, London, S.W.7, that he is making an investigation into the extent to which butterflies in the perfect or imaginal state are preyed upon in the British Isles by birds, and he would be glad to have any first-hand observations, giving, where possible, the species of both butterfly and bird, the date and locality, details of mode of capture, etc. Wings detached by the bird are of value, both as evidence of identity, and also by reason of the imprint of the bird's beak which is sometimes shown. Published records up to and including the year 1908 have been summarised in a paper by Sir Guy Marshall entitled, "Birds as a Factor in the Production of Mimetic Resemblances among Butterflies" (Trans. Ent. Soc. Lond., 329-383, 1909). Mr. Collenette is making a search in both entomological and ornithological literature for British records published since this date, and he would be pleased to receive references especially in the lesser-known publications.

\section{Announcements}

A Discussion on "The Raman Effect in Relation to Some Chemical Problems", to be opened by Dr. J. J. Fox, will be held at the Chemical Society on February 16, at 8 P.M.

Dr. S. Courtauld, a trustee of the National Gallery and founder of the Courtauld Institute of Art, Mr. E. G. V. Knox, editor of Punch, and Dr. N. V. Sidgwick, F.R.S., fellow of Lincoln College, Oxford, and member of the Advisory Council of Scientific and Industrial Research, have been elected members of the Athenæum under the provisions of Rule II of the Club, which empowers the annual election by the Committee of a certain number of persons of distinguished eminence in science, literature, the arts or for public service.

THE next sectional meeting of the World Power Conference will be held at Stockholm on June 28July 4. Reference was made to the programme in connexion with this meeting in NATURE of January 7, p. 22. Forms of application for membership can be obtained from the British National Committee, World Power Conference, 63, Lincoln's Inn Fields, London, W.C.2.

The following have been elected officers of the Royal Meteorological Society for 1933 :-President : Prof. S. Chapman; Hon. Treasurer: Mr. R. A. Watson Watt ; Hon. Secretaries : Dr. J. Glasspoole; Mr. W. M. Witchell, and Dr. A. Crichton Mitchell; Foreign Secretary: Capt. C. J. P. Cave; New Members of Council : Mr. J. H. Field, Dr. B. A. Keen, Capt. W. N. McClean, and Dr. F. J. W. Whipple.

THE Central Scientific Company of Chicago has issued the first two numbers of a bulletin entitled Cenco News Chats which is meant to furnish to the public interested in instruments an up-to-date account of new developments in apparatus for which the Company is responsible. It is less formal than a catalogue, is well illustrated and does not enter into scientific details. We learn from it that the Bunsen burner with an $\mathrm{H}$ base with side entrance for gas and bottom for air is the most popular, and that the wire gauze over the flame should be iron 16 mils in diameter and 16 to the inch. Spectra photographed by means of a Wallace concave grating replica with a ruled surface only $28 \mathrm{~mm}$. by $20 \mathrm{~mm}$. are reproduced, and a short account of the Hahn X-ray spectrograph is given. Copies of the News Chats may be obtained on request from Messrs. Edwards, Allendale Road, London, S.E.5.

Applicatrons are invited for the following appointments, on or before the dates mentioned :-A temporary inspector in the Markets Division of the Ministry of Agriculture and Fisheries-The Secretary, Ministry of Agriculture and Fisheries, 10, Whitehall Place, London, S.W.1 (Feb. 20). A principal and head master of the Maidstone Technical Institute and Junior Technical School-Mr. A. W. Peacock, Education Department, Tonbridge Road, Maidstone (Feb. 25 ). 